\title{
The legacy of singing Scripture only in the Reformed Churches in South Africa: The regulating role of the Word from Heidelberg to Dordrecht
}

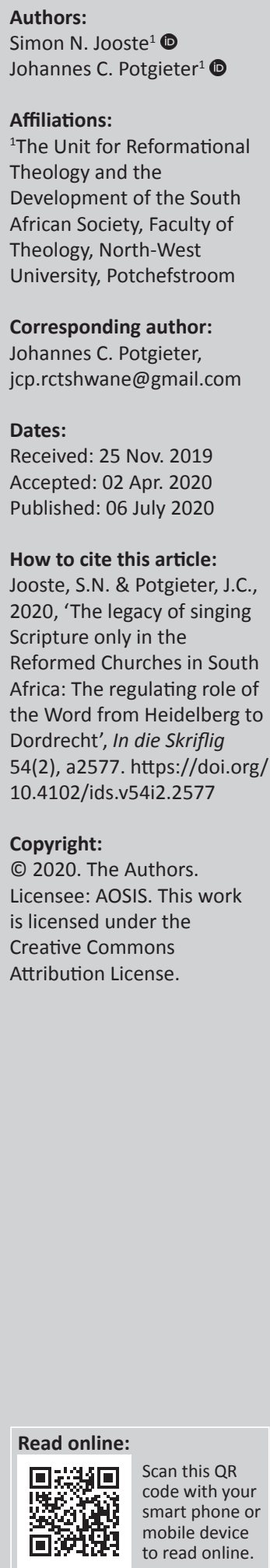

This article presents a historical-theological investigation into, and retrieval of, the principle underlying Article 69 of the 1618-1619 church order of the Synod of Dordrecht for the reformation of worship in the Reformed Churches in South Africa (RCSA). Article 69 essentially mandates the singing of Scripture only in corporate worship. The Dordrecht church order was adopted by the RCSA (originally the Vrye Gereformeerde Kerk) at her founding in 1859, a founding in part as a reaction to the singing of free hymns in the mother Nederduitsch Hervormde Kerk. In her formation, the RCSA re-established vital continuity with a catholic and Reformed tradition of singing Scripture only in public worship. And yet, in 2012, the General Synod of the RCSA decided to revise Article 69 to allow for the singing of free hymns. In the name of Semper Reformanda, this article seeks to challenge the historical-theological validity of this decision by recovering a central principle overlooked at the aforementioned Synod, yet present in the continental Reformed tradition. That principle is the Scriptural or regulative principle of worship (S/RPW). Simply stated, it is doing in public worship only what God commands. The presence of the S/RPW in the founding standards of the RCSA is of significance for appreciating her historic 150-year legacy of singing Scripture only and for her ongoing responsible critique of introducing free hymns.

Keywords: RCSA; Synod of Dordrecht; Three forms of unity; Regulative principle of worship; Worship; Covenant.

\section{Introduction}

The key question to be explored in this article is whether the Reformed Churches in South Africa (RCSA) possesses within her tradition the resources to perpetuate her predominating legacy of singing Scripture only. Did her 2012 General Synod decision ${ }^{1}$ to revise Article 69 of her (Dordrechtmodelled) church order and permit free hymns ${ }^{2}$ signal the end of further historical and theological inquiry into the merits of this legacy?

To answer this question, this article provides historic evidence for the scriptural or regulative principle of worship (S/RPW) 3 underlying the original formulation of Article 69 of the church order of Dordrecht by beginning with the Three Forms of Unity. These forms - the Heidelberg Catechism, the Belgic Confession and the Canons of Dordrecht - are not only historical precursors to the RCSA's original church order but continue to serve as the ongoing interpretive lens for understanding what Scripture and the Reformed tradition teach on the theology and practice of singing in worship. In addition to the Three Forms, other select figures and events leading up to the 1618-1619 Synod of Dordrecht will be examined.

\section{Principles for worship: Some confessional co-ordinates}

Like historic Presbyterians and Lutherans, the Reformed tradition is inherently confessional. This means her identity and practice have been shaped by agreed-upon creedal statements, from

1.'In the churches only the 150 Psalms and the rhymed versions of the Ten Commandments, the Lord's Prayer, the Apostolic Confession, and the Hymns of praise of Mary, Zacharias and Simeon shall be sung. The use of other rhymed versions of Bible verses and Scriptural faithful hymns which have been approved by the Synod, is left over to the jurisdiction of each church council [the churches]' (RCSA 2012:379-380)

2.For the purposes of this article, a free hymn is understood to be a song composed and sung that is not a metrical versification of the actual words of Scripture (cf. RCSA 2012:384-385). Furthermore, we understand that the term 'Scriptural faithful hymns' included in the RCSA 2012 revision of Article 69 fits the preceding definition of 'free hymns' and is a distinct additional category to Psalms, Scripture versification ('rhymed versions of Bible verses') and confessional songs. 
Calvin's Ecclesiastical Ordinances to the Three Forms of Unity. The continental Reformed symbols are a faithful summation of what the Bible teaches. Therefore, it should be of no surprise that they have much to say about worship.

\section{God and covenant}

Mostly implicit to the Three Forms and its teaching on worship is the covenant relationship between God and his people. While the term is only mentioned five times (HC 1983: Questions 74, 77, 79), the concept nevertheless emerges organically (Brown 2015). ${ }^{4}$ God is King over heaven and earth as the chief architect of creation and salvation (BC 1983: art. 1-2; HC 1983: LD 9-10). In the infinite perfections of his divine being, he is wholly other than what he has created (BC 1983: art. 1; HC 1983: LD 34-7). God is sovereign Lord and man is his servant (LD 34; CoD 1983: head I; HC 1983: Questions 26-27). As perfectly holy and just, God has graciously chosen to freely act for his glory in creating and redeeming sinners - to make them into worshippers. Throughout the Bible, God has progressively unveiled his plan of salvation through various covenants culminating with the new covenant sealed in Christ's blood (cf. especially, BC 1983: art.1, 8, 10-26; CoD 1983: heads II-IV; HC 1983: Questions 1-23). Basically understood, a biblical covenant is a formal agreement that creates a relationship between God and his people with legal aspects (Brown \& Keele 2012). ${ }^{5}$

It is beyond the scope of this article to defend at length the claim that the doctrine of covenant substantively undergirds the continental Reformed standards (cf. e.g. Beach 2010; Brown 2015; Estelle et al. 2009; Ursinus 1992:97-99; Woolsey 2012). Suffice to say and for starters, although increasingly contested in more recent times, there is a robust body of contemporary Reformed scholarship defending the notion that the Three Forms depicts God entering into a covenant of works with Adam prior to the Fall (cf. e.g. Beach 2010; Brown 2015; Estelle et al. 2009). ${ }^{6}$ Evidence for this is found, for one, in that Adam is portrayed as created in the image of God in a state of holiness, righteousness and goodness, with obligations inherent to this state. He was to live a life in conformity with the sanctity of the divine image (BC 1983: art. 14; CoD 1983: heads III/IV: 1; HC 1983: Questions 6-8). The Belgic Confession states that Adam was given the 'commandment of life' - not to eat of the tree of the knowledge of good and evil - which in the end he transgressed, thereby violating the whole law (BC 1983: art. 14). Secondly, Adam was created and put to test as the federal representative of the human race. When he failed to live out the divine image and transgressed the commandment, all his posterity fell in him (BC 1983: art. 15; CoD 1983: heads III/IV:2-3; HC 1983:

4.One reason why the doctrine of covenant is not more explicitly and frequently handled is because of its instructive purposes for children.

5.Robertson's (1987) definition of a covenant - 'a bond in blood sovereignly administered' - is helpful. However, it does not do justice to the reality of covenants in the Bible that did not involve the shedding of blood, like the pre-fall covenant of works and God's covenant with Noah.

6.Earlier classic Reformed theologians defending the doctrine of a covenant of works include Francis Turretin, A.A. Hodge, Abraham Kuyper, Herman Bavinck and Louis Berkhof (Beach 2010:104-105).
Questions 6-8). Although Adam and Eve had the ability to obey God's law, they rebelled against God and came under his just and supreme punishment for law-breaking (BC 1983: art. 14-15; CoD 1983: heads III/IV:1; HC 1983: Questions 9-11). While the language of covenant of works prior to the fall is not explicitly present in the Three Forms, the elements are there, namely federal representation, the standard of legal conditions, and sanctions and actual punishment for covenant-breaking.

With the covenant of works as the critical and illumining backdrop, the Three Forms also substantively set forth the (less contested) constituent elements of the covenant of grace. Far from setting aside the perfect legal standard, Christ the Mediator fulfils all righteousness, thereby rescuing sinners from divine judgement. In doing so, Jesus acts as the justified second Adam whose perfect obedience is imputed to those guilty in the first Adam, who receive it by faith (BC 1983: art. 17-18, 20, 20-25; CoD 1983: heads I, 2, II:1-4, 9; HC 1983: Questions 12, 15-18, 20, 36, 59-60). The Reformers understood that the Gospel message would be lost without the anchoring of its twofold covenantal foundation (Brown 2015).

It is in light of God's choice to relate to man in the context of covenant that worship should be understood. Our same Lord who sets the terms of the covenant is the one who determines how he is to be worshipped. In keeping with the Reformation banner of Sola Scriptura (cf. BC 1983: arts. 3-7, 32), just as sinners are not left in the dark, as to the way of salvation, they are not left wondering how God wants his covenant people to respond to him in public worship (Clark 2008:261, 281; cf. Ex 19:7-8). And, yet, sinful man has always been prone to think and act otherwise.

\section{Sin and the perverse imagination of man}

In the garden of Eden, God communed with man whom he had created righteous and holy. Man was able to do things agreeable to the will of God. And yet, Adam transgressed the commandment of life that he had received. On account of original sin, Adam and all mankind have been separated from God. They are by nature wicked, perverse and corrupt in all their ways, and thus, unable to know or do God's will (BC 1983: art. 14-15; CoD 1983: heads 3-4:1-5; HC 1983: LD $2-3)$. As a result, the natural man hates God. Steeped in his own wisdom and wallowing in self-worship, he engages in serial idolatry (BC 1983: art. 36; HC 1983: LD 2, 35-36; cf. Ursinus 1992:506-549). Such is the plight of sinful man. And yet, even the redeemed, regenerated and those indwelt by the Spirit struggle to discern and follow through on the will of God. The saints are so weak - beset by all manner of temptations at the hands of the world, the flesh and the devil - that they cannot stand for a moment, without the preserving and strengthening work of the Spirit (CoD 1983: heads 5:1-4; HC 1983: LD 44, 52).

If Adam required the commandment of life to guide his existence and worship in a state of uprightness, how much more does the church depend upon the revelation of God as 
that institution comprising sinners and saints? How necessary are the directives of God when it comes to the church's highest yet most abused calling: worship?

\section{The authority and sufficiency of the word}

As the covenant Lord, it is God's sovereign prerogative to determine the means by which he makes himself known for his glory and our salvation, which is the holy Word (BC 1983: art. 2). Endued with divine authority, the Word of God serves to regulate, found and confirm faith (BC 1983: art. 5). More specifically, as the manifestation of God's will and the all-sufficient rule of faith, 'the Holy Scriptures set forth the whole manner of worship that God requires of us' (emphasis ours). Therefore, all words of men intended to either add to or take away from this infallible rule are forbidden. '[W]e reject all human innovations and all laws imposed on us, in our worship of God, which bind and force our conscience in any way' (BC 1983: art. 32; emphasis ours). The Belgic Confession goes on to speak in other places about God's regulation of the life of the church at worship. For instance, the church is a creation of God's Word, outside of which there is ordinarily no salvation to be found. To withdraw from God's church is to act contrary to his ordinance (BC 1983: art. 27-28). Furthermore, the church, in order to be true to God and his Word, must display three essential marks: the pure preaching of the gospel, the pure administration of the sacraments that Christ instituted and the practice of church discipline. 'In short, it [the church] governs itself according to the pure Word of God, rejecting all things contrary to it and holding Jesus Christ as her only Head' (BC 1983: art. 29; emphasis ours). The discharge of these three marks entails a spiritual order taught in the Word, namely, the offices of minister, elder and deacon - with their respective preaching, ruling and service functions (BC 1983: art. 30-32). These are the ways in which the true church can be recognised. To be distinguished from her is the false church, which may easily be discovered wherever 'it assigns more authority to itself and its ordinances than to the Word of God' (BC 1983: art. 29).

\section{Worshipping God only as he commands}

The Heidelberg Catechism also speaks directly to those ways in which God wants his church to be governed, essentially repeating the three marks of a true church (see generally HC 1983: Part 2). Unlike the Belgic Confession, it uses the language of the keys to the kingdom according to the command of Christ (HC 1983: LD 31). Furthermore, the Catechism provides commentary on the first table of the Decalogue, which deals directly with public worship. In the First Commandment, the Lord commands that he alone be worshipped as the one true God. Anything contrary to this, his revealed will, is idolatry (HC 1983: LD 34; cf. Ursinus 1992:510). In the Second Commandment, God sets forth the manner, which he requires in worship. 'That we in no wise make any image of God, nor worship Him in any other way than He has commanded us in His Word'. For we should not presume to be wiser than God (HC 1983: LD 35). ${ }^{7}$ In the Third Commandment, God commands the form of worship, which should be without the sin of blasphemy - the greatest of all evils (HC 1983: LD 36; cf. Ursinus 1992:536-542). And in the Fourth Commandment, our covenant Lord prescribes the day on which he is to be worshipped publicly and how it is to be sanctified (HC 1983: LD 37).

Indeed, seeing that what is sung in worship are prayers offered up corporately, the Lord's Prayer - as the church's primary pattern - provides helpful insight into what pleases God. Most applicable, in the First Petition the church asks that God's name be magnified, praised and honoured, and not blasphemed. In the Second Petition, the faithful pray that the Kingdom of Christ would come insofar as the church is governed by God's Word and Spirit. In the Third Petition, the saints pray to God that his will be done on earth as it is in heaven as men obey his Word. It is worth drawing attention again to the Sixth Petition where it is prayed that God would keep his church from temptation and evil, which burns most fiercely around her loftiest duty: worship (HC 1983: LD 47-49, 52).

In short, to worship God only as he commands is in keeping with the tenor of the covenant relationship where God is the primary actor and his people are those who receive (cf. e.g. HC 1983: LD 25-31). The worship of the church is always in grateful response to the Word of the covenant Lord who commands, keeps those commands in his Son (HC 1983: LD 11-19), confirms his promises (questions 65-66), assures of salvation (question 73), graciously governs by his Spirit (question 76) and covers sin (question 81). This thankful response of those in Christ is by the Word of Christ given in Scripture. God gives what he commands the Christian through the Word and Spirit in the lisping praise of his redeemed people (HC 1983: LD 34-38). It seems reasonable to infer then that what God expects to be sung in corporate worship he gives in his Word, especially considering that worship is man's highest duty (Ursinus 1992:536-537).

\section{Liberty of conscience}

The movement of the Heidelberg Catechism from guilt under the law to grace received in Christ to free and grateful obedience is the witness of Scripture (HC 1983). ${ }^{8}$ The conscience of the believer is at once gloriously liberated from the law for justification and subject to it in sanctification (HC 1983: Part 3). We may speak of the latter as the regulative or Scriptural principle of the Christian life. We believe and confess that the infallible rule of Scripture contains the will of God for our salvation and the manner of worship he requires of us (BC 1983: art.7). Echoing Scripture, the Three Forms of Unity gives priority of place to the revelation of redemption

7..To worship God truly, is to worship him in the manner which he himself has prescribed in his word... This commandment forbids ... every form of will-worship, or such as is false, requiring that we neither regard or worship images and creatures or such as is false, requiring that we neither regard or worship images and creature for God, nor represent the true God by an image or figure, nor worship him at or by images, or with any other kind of worship which he himself has not prescribed.. Hence all kinds of worship not instituted by God, but by men, as well as those which contain the same reason why they should be prohibited, are forbidden in this
precept of the Decalogue' (Ursinus 1992:1518).

8.The Heidelberg Catechism seeks to follow the example of Paul's letter to the Romans. 
in Christ and the necessity of repentance and faith. The next order of attention is given to the chief duty of saved sinners, which is the public worship of God in the context of the church: from the day, manner and form, to the officers, elements and fellowship involved. In turn, our confessional standards set forth the church's duties of discipline, prayer and love for one's neighbour.

While the minister of the Word and ruling elders, who hold the keys to the Kingdom of Heaven (HC 1983: LD 31), are to govern the lives of members of Christ's church on the basis of the Word, they may not add to or subtract to that revelation for justification or sanctification (BC 1983: art.7). Lest they be guilty of legalistic imposition on the conscience of the believer (BC 1983: art. 32). Hence, while Scripture calls believers to live all of life by faith according to the law unto God's glory (HC 1983: Question 91), God has not revealed many of the specifics of how that is worked out in communities and institutions beyond the church. Therefore, where the Bible is silent, the church may not bind the conscience of her members but must allow freedom of choice within the confines of the broader precepts of God's revealed moral law. In matters ranging from building bridges and casting one's vote to bioethics, the Christian must exercise wisdom derived from the light of nature (BC 1983: art.2; CoD 1983: head III-IV, 4; cf. Jooste 2019:192-194; VanDrunen 2010a:161-205; Vorster 2016). In short, the doctrine of God's Word regulating worship and the broader lives of Christians has its limits. This is why the Reformed tradition has held to a robust teaching of God's common grace or natural law, which informs decisionmaking relative to vocation and earthly citizenship (cf. Jooste 2013; VanDrunen 2010a, 2010b, 2014; Vorster 2010).

What is sung in public worship is one concrete and critical example of where the conscience of the worshipper must be safeguarded (cf. BC 1983: art. 7, 32). The minister and elders may dictate the responsive praise of the believer in the divine service with the Word only. Indeed, the ordained minister may preach and pray expositions of the Word of God. This freedom is in keeping with the nature of the special office he fulfils (cf. BC 1983: art. 30-2; HC LD 31). However, lay persons - who hold the general offices of prophet, priest and king (cf. BC 1983: art. 28; HC LD 12) - in responding to God's Word can have no difficulty of conscience with singing the Word of God only (cf. HC 1983: LD 35). However, to put in the mouths of worshippers the words of men is to bind and force the conscience where it is free, and in the most crucial responsive act of the Christian in a saving covenant relationship with God (cf. BC 1983: art. 7, 32).

\section{God's regulation of worship}

The aforementioned confessional section serves as the lens through which to return to Article 69 of the 1618-1619 Synod of Dort concerning what is to be sung in corporate worship. If our church order is the practical application of our confession (norma ministrans), it only makes sense that our confessions (norma normata) are the lens through which we read and interpret our church order. Our purpose then is to discover what principle lay behind an article that has had such a formative influence upon the global Reformed tradition, including South Africa. An historical reading of parts of the Three Forms of Unity, like the one above, suggests that the fundamental conviction underlying the desire to sing the Word of God only is what has become known as the regulative principle of worship.

What remains in the sections to follow is to test this thesis by considering principled reasoning behind singing Scripture only in select precursors and successors to the formulation of Article 69 of Dort, and with a specific eye on the South African context.

\section{The Synod of Dort and worship}

The Synod of Dort that convened in the Dutch town of Dordrecht during 1618-1619 is best known for its formulation of the Canons of Dort. And, yet, not unrelated to and arguably even more important than this seminal Reformed creedal statement is the church order and the accompanying liturgical order of worship that this church assembly produced. Informed by the grand doctrines of God's sovereign election, the authority of God's covenant Word, man's sinful depravity, the bondage of the human will and redemption in Jesus Christ set forth in the Canons, Article 69 of the church order of Dordrecht essentially mandates the singing of Scripture only.

Was this prescription a unique quirk in the history of the church? Was it motivated by historical circumstances only? Or did it build upon substantive insights of the historic catholic church?

\section{Select precursors to Dort Church Fathers}

It is beyond the scope of this article to investigate what exactly was sung during corporate worship services in the early New Testament church. It seems safe to assume that Jesus as a Jew at the closing of the Old Testament order sang Psalms only. More contested, no doubt, is the claim that the Apostolic church also only sang the songs found in God's Word. Central to the thesis of this article is that the evidence in the post-Apostolic church strongly suggests reading the Scriptural witness in this light.

The first few hundred years of the New Testament church gives little evidence of uninspired hymn singing (Oliphant Old 2002:47; cf. Oliphant Old 1975). Of the four earliest witnesses, 1 Clement (96 AD), The Didache (80-100 AD), Ignatius' Epistles (108 AD) and Pliny's letter to Trajan (110 AD), only the last suggests the singing of a non-canonical text. Otherwise, the predominant practice in the early Patristic era was the singing of Psalms. Ancient church historian Eusebius of Caesarea (263-339 AD) supported these earliest witnesses with the following words quoted in Wagner (1901):

$[T]$ he command to sing psalms in the name of the Lord was obeyed by everyone in every place: for the command to sing psalms is in force in all Churches which exist among the nations, not only for 
the Greeks but also for the Barbarians; and further, throughout the whole world, in towns and villages and in the fields also, in short, in the whole Church, the people of Christ, who are gathered from all nations, sing to the one God, whom the prophets foretold, hymns and psalms with a loud voice, so that the voice of the psalm-singers is heard by those standing outside. (p. 7)

By the fourth century, the church began to introduce more readily uninspired hymns, especially among the Gnostics in the East. And, yet, this emergent practice was not without creedal resistance. For example, The Council of Laodicea (363-5), The Council of Chalcedon (451), The Council of Braga (561-3), The Second Council of Nicea (587) and The Fourth Council of Toledo (633), all prohibited the singing of anything but the Biblical text (Bushell 1999:154-167). Further evidence may also be marshalled from the orders of worship preserved from the Patristic period, of which all indicate the singing of Psalms (Maxwell 1936).

Final explicit patristic support for the singing of Psalms comes from St. Augustine at the dawn of the Middle Ages. In his preface to the 1543 Genevan Psalter, Calvin (1543b) cited the North African churchman in defence of the custom of singing Psalms in the ancient church:

Now what Saint Augustine says is true, that no one is able to sing things worthy of God unless he has received them from him. Wherefore, when we have looked thoroughly everywhere and searched high and low, we shall find no better songs nor more appropriate for the purpose than the Psalms of David, which the Holy Spirit made and spoke through him. And furthermore, when we sing them, we are certain that God puts the words in our mouths, as if he himself were singing in us to exalt his glory. (n.p.)

Two final lines of evidence giving indirect support for the predominant practice of singing Scripture only in the early post-Apostolic church are the absence of musical accompaniment and the observance of the liturgical calendar. Like the general refraining from singing free hymns, the church fathers found no basis in the Word of God for instruments facilitating New Testament corporate worship (Clark 2008:227-291) or the calling of special worship services to celebrate feast days (Williamson 2001).

However, the Middle Ages would see these early catholic church practices change. Alongside a more fully entrenched version of Constantinianism and the conflation of law and Gospel, the Medieval Roman Catholic Church progressively encouraged the singing of uninspired hymns accompanied by musical instrumentation (Clark 2008:246-247; cf. Oliphant Old 2002:47-49). This interlude of about a 1000 years set the stage for the Protestant Reformation, which saw a return to the pattern of worship practiced by the Apostles and in the early post-apostolic church.

\section{Calvin and the Calvinists}

The second-generation Reformer, John Calvin (1509-1564), is inescapably influential upon the theological formation of the early continental Reformed tradition and what has otherwise since become known as Calvinism. Evidence pertinent to this article is the fact that among those commissioned to draw up the Heidelberg Catechism, Zacharias Ursinus (1534-1583) and Caspar Olevianus (1536-1587) were influenced by Calvin's theology and practice of worship. In addition to providing counsel to the likes of John Knox (1513-1572) and John Hooper (1495-1555), the Genevan Pastor's theology of worship would also leave a significant imprint upon the formulation of the Westminster Standards in 1644, especially the penning of the Directory of Public Worship - and not least through the mediating influences of the Heidelberg Catechism and Ursinus' commentary on the same (Clark 2010:266-269).

Before considering briefly Calvin's theology and practice of worship as it pertains to singing, it is significant to note that he considered worship to be the most important part of religion, next to the article of justification by faith alone (Calvin 1543a; cf. Inst. 2.8.11). In part, this assertion rests on his conviction that because the first four commandments deal directly with worship, worship is to be the foundation of righteousness. To render to God false worship - to commit idolatry - is to rob God and destroy the basis of true godliness (Inst. 2.3.11). Yet, it is not as if the law of worship is at odds with the Gospel of free grace. The true worship of God comprehends and is premised upon the doctrine of justification (Inst. 3.6.1). Sinners are redeemed for the duty of glorifying God's name in worship. And corporate worship is the chief means by which sinners are saved and in turn persevered in the faith (see title and contents of Inst. 2-3).

Building upon and refining the insights of the church fathers, St. Augustine and Martin Luther, Calvin's burden for the reorganisation of worship in Geneva is evident as early as the 1536 edition of the Institutes. In January 1537, the Swiss Reformer along with his ministerial colleagues submitted themselves to the Council of Articles Concerning the Organisation of the Church and Worship in Geneva. Among the liturgical reforms set forth were the request for weekly communion, the election of elders, the institution of church discipline and that congregations sing Psalms in accord with the practice of the ancient church and Paul himself (Clark 2010:247-248; Institutes 1536; ed. McNeill 1954:47-55). Calvin's renewed stress on the Word of God was particularly evident - amidst the removal of images, colourful vestments, choirs and organs, and the pomp of the Mass - in exegetical sermons and congregational singing from the Old Testament Psalter. The creation of the Genevan Psalter 'established psalmsinging as the pattern for Protestant worship outside Lutheran and Anabaptist circles that would prevail for at least three centuries (in some places five)' (Hart 2013:19). ${ }^{9}$ Calvin cared not only that the one true God be worshipped, but that he be worshipped in the right way. The Reformer believed in the importance of both content and form.

9.For further evidence of Calvin's practice of essentially Psalm-singing only, see the Genevan liturgy in Clark (2008:282-284). On Calvin's use of the (only) non-canonical text in corporate worship, the Apostles' Creed, most likely (only) non-canonical text in corporate worship, the Apostles Creed, most likely because of its quasicanonical quality and pedagogical function, see Clark (2010:265). Noteworthy is the fact that over time the inclusion of the Apostles' Creed was not deemed in keeping with Calvin's principle of worship. Later editions of the Genevan Psalter did no provide metrical translations of the Apostles' Creed. From 1563 onwards, the Psalters only included, in addition to the 150 Psalms, metrical translations of the Ten Commandments and the Song of Simeon. For an elaboration of the changes that Calvin made to late-medieval worship in Geneva, see Manetsch (2015:31-36). 
While Calvin is arguably well-known for many of his church polity and liturgical reforms away from the medieval Roman Catholic church, although perhaps less for his acapella Psalm-singing, the central theological principle behind his reorganisation efforts in Geneva has become shrouded in obscurity (Clark 2010). Nevertheless, there is ample testimony in Calvin's corpus to the effect that only what God has commanded in Scripture is permissible in public worship. This, Calvin's principle of worship, would later become coined the regulative principle of worship - a principle that would gain widespread acceptance and gradual refinement from 16th-century Geneva to the writing of the Heidelberg Catechism and the work of the Westminster Assembly. ${ }^{10}$

As indicated above, as early as 1537 Calvin demonstrated his belief that corporate worship should embody the will of God revealed in Scripture. That this conviction was not an idiosyncrasy of the early Reformer is evidenced throughout his literary output, both in terms of systematic theological treatise and Biblical commentaries. Indicative of the former is Calvin's contention in the 1559 edition of the Institutes that the reverence due to God is to 'worship him as he commands, mingling no inventions of our own' (Inst. 4.10.23; cf. 4.10.30; 3.11.1). For to give way to the imaginations of men is to corrupt worship and be guilty of idolatry (Inst. 4.10.23-26; cf. e.g. 1.11.8.; 4.10.11). In terms of Calvin's commentaries on the Bible, one particularly striking formulation of his principle of worship occurs in his handling of the Second Commandment in Exodus 20.11 Also, noteworthy in his polemical writings are the comments made in the Necessity of Reforming the Church (ed. McNeill 1954) and the 1548 Leipzig Interim (Clark 2008:248).

In defending the practice of singing Scripture only on the theological basis of doing what God has commanded, Calvin saw himself as continuing the tradition of the Apostles and the early church. This same tradition has found significant continuity in the later Reformed and Calvinist witness. While the practice may have lagged (Clark 2010:258-263), the theological principle behind the singing of Scripture only in corporate worship became ever more robust and refined over time. Beginning with Zwingli, Oecolampadius, Bucer and the Swiss-German Reformers, a consensus gradually spread with the help of Calvin to the French, German and Dutch Reformed. ${ }^{12}$ Beyond the continent, this phenomenon crystallised among the English and Scottish Presbyterians and Puritans. In England, the English Puritan tradition

10.For secondary sources defending this claim as well as engaging the contemporary discourse, see, for example, Clark (2010); Clark (2008:227-229); Manetsch (2015:34-35) and Gordon (2003).

11.See also, for example, Calvin's ([1559] 2006) commentaries on Exodus 32; Leviticus 10: 1-3; Matthew 15: 9; and Colossians 2: 23. See also his commentary on Leviticus 10: 1; 22: 32; Numbers 15: 39; Deuteronomy 4: 1; 12: 32; 2 Samuel 6: 6-12; Isaiah 29: 14; Jeremiah 7: 21-24; 7: 31; 19: 4.5; 26: 2; Matthew 15: 1.9; Colossians 2: 22 23; and Inst.: $1.12 .1 ; 1.12 .3 ; 2.7 .5 ; 2.8 .17$; 4.10.1, 8-11, 16-18, 23, 24, 26. Calvin [1559] 2006

12.While the preference and practice of Calvin's Geneva generally prevailed in the continental Reformed churches, not all agreed initially that the regulative principle limits what is sung in corporate worship. At the outset, some of the Reformed churches also produced hymns for singing in church. The Constance Hymn Book of 1540 is a famous example, as well as the psalter-hymnal produced by the church in Strasbourg (Oliphant Old 2002:47-53). arguably reached its zenith at the Westminster Assembly in 1644 with the Directory of Public Worship espousing the singing of Psalms only on the basis of what had become known as the regulative principle of worship found in the Westminster Confession of Faith (Clark 2008:248-249). ${ }^{13}$

Yet, perhaps the theology behind singing Scripture only is in fact more Calvin's quirk fuelled by English Puritan novelty read back into the Three Forms of Unity? Is Calvin's principle of worship or the regulative principle of worship indeed a thoroughgoing category in the continental Reformed tradition? To help further answer this important question, it seems only natural that one examines the theology behind the formulation of Article 69 of the church order at the Synod of Dort (1618-1619).

\section{Earlier Dutch Reformed Synods}

A brief consideration is now given to three significant Dutch Reformed Synods leading up to the pivotal Synod of Dort in 1618-1619. With the exception of the Remonstrant Provincial Synod of Utrecht, 1612, in all the church orders set forth at the Convent of Wesel (1568), Dort (1574 and 1578), Middelburg (1581) and Gravenhage (1586), the wording is unambiguous to the effect that only the Psalms of David are to be sung in the church (and hymns should be omitted because they are not found in Scripture) (De Ridder 1987). It is assumed that these ecclesiastical charters, while giving practical directives, are nevertheless at their root the fruition of theological deliberation. In other words, like the church order that would later be formulated at Dort in the early 17 th century, these documents reflect ecclesiastical consensus on what Scripture teaches - and in turn confessed in the Heidelberg Catechism and Belgic Confession - regarding, among other things and chiefly, corporate worship. Hence, it seems reasonable to conclude that what one finds in these early Dutch Reformed Synods is an underlying principle of worship sharing continuity with the catholic and Calvinist traditions, namely, to essentially sing Scripture only. It seems not coincidental that the church order of the Synod of Dort (1578) in Article 76 states: 'The Psalms of David translated by Pieter Datheen shall be sung in the Christian gatherings of the Netherlands churches as has been done until now, excluding the hymns which are not found in the Bible' (De Ridder 1987:220).

\section{Dort 1618-1619 and Article 69: Singing Scripture only}

By the time of the Synod of Dort in 1618-1619, the streams of patristic, Calvinist and Reformed influence had been pooled in an attempt to heed the Scriptural injunction to worship God only as he commands. A summary of this wisdom can be found in the Three Forms of Unity and the (1618-1619) church order of Dort, all of which had been adopted as the ecclesiastical standards of the Reformed Church of the Netherlands by the closure of this historic Synod (Clark 2010:183-184). 13.With regard to those places in the Westminster Confession that set forth the
regulative principle of worship, see $\operatorname{WCF}(1983: 1: 6 ; 21: 1 ; 22: 2,31: 3)$. For the thesis of Calvin against the Calvinists, see Muller (2000). 
Like Calvin (cf. Clark 2010:258-69), seeking to further the Protestant reformation in Geneva, the delegates to the Dutch Reformed Synod that convened during 1618-1619 in the town of Dordrecht sought to do the same in a less than ideal context. Among others, churches were still recovering from the influence of medieval Catholicism, had to contend with the controlling influence of the civil magistrate ${ }^{14}$ and a short supply of educated Reformed ministers. Hence, it should not come at a surprise that by the early 17th-century not all churches in Holland were singing Scripture only. And, thus, the wording of Article 69 of the church order formulated at this time (during session 162) reflects an attempt at applying pastoral wisdom to a tenuous ecclesiastical and political situation (Clark 2008:253-254).

The exact formulation of the article under our consideration is as follows (per De Ridder 1987):

In the churches only the 150 Psalms of David, the Ten Commandments, the Lord's Prayer, the 12 Articles of Faith, the Songs of Mary, Zacharias, and Simeon shall be sung. It is left to the option of the churches whether to use or omit the song, ' $\mathrm{O}$ God, who art our Father'. (p. 555) ${ }^{15}$

An uninformed and superficial reading of these words would suggest a revision of the underlying theological principle informing Synodical decisions to sing Psalms or Scripture only to this point. Not only is there a widening of what is permissible to sing from the Bible, but there is also provision for the singing of the 12 Articles of Faith (the Apostles' Creed) and another non-Scriptural hymn. At least three important observations are in order at this juncture. Firstly, while perhaps difficult for the modern church to appreciate, the Apostles' Creed at the time of the famous Synod of Dort was still likely deemed to have had quasi-canonical status ${ }^{16}$ and instructional value in promoting church unity (Clark 2010:265). Secondly, and to fill out further the political contextual circumstances touched on above, the Pastors and elders delegated to the Synod saw it necessary - like Calvin before them - to bring about reformation slowly, so as not to divide the Dutch churches with their somewhat divergent practices unnecessarily. Thirdly, the delegates to the 16181619 Synod would not have foreseen that their ecclesiastical efforts would be curtailed by political dissension, thereby halting the unfolding process of semper reformanda for many years (Clark 2008:254). Hence, in short, it seems reasonable to conclude that when combining the above

14.As an example of the influence of the civil magistrate, see Article 22 of the 1583 'Ecclesiastical laws prepared by order of the Magistrates of Holland' as well as Article 23 of the 1591 'Church order designed by certain political and ecclesiastical persons at the Hague' (De Ridder 1987:320,433). Both of these articles required persons at the Hague' (De Ridder 1987:320, 433). Both of these articles required
the churches to sing the Psalms of David, the Ten Commandments, the Songs of the churches to sing the Psalms of David, the Ten Commandments, the Songs of
Mary, Zechariah and Simeon, the Apostles' Creed and the Lord's Prayer, but no other songs.

15.The actual report of Session 162 of the Synod, out of which the formulation of the Article 69 was derived, is as follows: 'In the churches only the 150 Psalms of David, the Ten Commandments, the Lord's Prayer, the Twelve Articles of Faith, and the Songs of Mary, Zacharias and Simeon shall be sung. Whether or not to use the hymn, "O God who art our Father," etc. is left to the freedom of the churches. Al other hymns shall be kept out of the churches, and where some have already been introduced they shall be discontinued by the most appropriate means. Art 69 " (see De Ridder 1987:565).

16.'[T]ill the middle of the 17th century it was the current belief of Roman Catholic and Protestant Christendom that the Apostles' Creed was 'Membratim articulatimque' composed by the Apostles in Jerusalem on the day of Pentecost...' (Schaff 1983, vol. 1: 22) extenuating circumstances with scant authoritative theological argumentation to the contrary, the Calvinist principle of worship informing the Dutch Reformed church's orders, running from Wezel 1568 to Dort 1618-1619 and Drente 1638, could not be brought to full realisation, in spite of what appears to be the best of pastoral intentions.

\section{Conclusion}

While it is indeed true that with time a significant contingency of churches would increasingly sing hymns not found in Scripture, the Calvinist and early Reformed legacy of singing Scripture only would live on in continental Europe and beyond (Clark 2008:254-257). However, this latter practice since the early reformation has not always been on the theological basis of Calvin's principle of worship or what has later become known as the S/RPW - thereby adding an additional challenge to the modern quest for the reformation of worship. One poignant example of the unfolding of this chapter in the worship story is the RCSA: a contested site for the successors to Dort. Can a federation with such a rich history of singing Scripture only further renew her theology and practice by utilising more explicitly a category that emerges out of her confessional and Reformed heritage, namely, the S/RPW? And especially in the wake of her 2012 decision to allow for the singing of free hymns? This article has made a case for the recovery of the S/RPW in a historic Reformed and confessional key. To further this case, additional historical inquiry is encouraged into the theology and practice of song in worship in the RCSA from 1859 to the present.

\section{Acknowledgements}

The authors are grateful for the feedback they received from individuals at the festival conference held by the Theological School in Potchefstroom from 18 to 20 September 2019.

\section{Competing interests}

The authors declare that they have no financial or personal relationships that may have inappropriately influenced them in writing this paper.

\section{Authors' contributions}

This article is the outcome of a joint research project to which both authors contributed. S.N.J. wrote the majority of the article and provided the initial conceptual framework. J.C.P. assisted with resources, revisions and formulation of concepts.

\section{Funding information}

This research received no specific grant from any funding agency in the public, commercial or-not-for-profit sectors.

\section{Data availability statement}

Data sharing is not applicable to this article as no new data were created or analysed in this study. 


\section{Disclaimer}

The views and opinions expressed in this article are those of the authors and do not necessarily reflect the official policy or position of any affiliated agency of the authors.

\section{References}

Beach, M.J., 2010, 'Some observations about the three forms of unity and the doctrine of the covenant of works', Mid-America Journal of Theology 21, 103-119.

Brown, M.G., 2015, 'The covenantal foundation of the Heidelberg catechism', Puritan Reformed Journal 1, 88-102.

Brown, M.G. \& Keele, Z., 2012, Sacred bond: Covenant theology explored, Reformed Fellowship, Inc., Middleville, MI.

Bushell, M., 1999, Songs of Zion: A contemporary case for exclusive Psalmody 3rd edn., Norfolk Press, Norfolk, VA.

Calvin, J., n.d., 'Calvin's commentaries', Christian Classics Ethereal Library, viewed 01 April 2020, from http://www.ccel.org/ccel/calvin/commentaries.i.html.

Calvin, J., 1543a, The necessity of reforming the church, viewed 01 April 2020, from https://www.monergism.com/thethreshold/sdg/calvin_necessityreform.html.

Calvin, J., 1543b, The preface to the 1543 Genevan Psalter, viewed 01 April 2020, from https://www.ccel.org/ccel/ccel/eee/files/calvinps.htm.

Calvin, J., [1559] 2006, Institutes of the Christian religion, transI. F.L. Battles, J.T. McNeil (ed.), 2 vols., Westminster Press, Philadelphia, PA.

Clark, R.S., 2008, Recovering the reformed confession, P\&R Publishing, Phillipsburg, NJ.

Clark, R.S, 2010, 'Calvin's principle of worship', in D. Hall (ed.), Tributes to John Calvin: A celebration of his quincentenary, pp. 247-269, P\&R Publishing, Phillipsburg, NJ.

Canons of Dort, [1619] 1983, 'The Canons of Dort', in P. Schaff (ed.), The creeds of Christendom, 3 vols., pp. 581-597, Baker, Grand Rapids, MI.

De Bres, G., [1561] 1983, 'The Belgic Confession', in P. Schaff (ed.), The creeds of Christendom, 3 vols., pp. 383-436, Baker, Grand Rapids, MI.

De Ridder, R.R., 1987, The church orders of the sixteenth century reformed churches of the Netherlands together with their social, political and ecclesiastical context, Calvin Theological Seminary, Grand Rapids, MI.

Estelle, B., Fesko, J.V. \& VanDrunen, D., 2009, The law is not of faith: Essays on works and grace in the mosaic covenant, P\&R Publishing, Phillipsburg, NJ.

Gordon, T.D., 2003, 'The Westminster assembly's unworkable and unscriptural view of worship?', Westminster Theological Journal 65, 345-356.

Hart, D.G., 2013, Calvinism: A history, Yale University Press, New Haven, CT.

Inst. see Calvin [1559] 2006.

Jooste, S.N., 2013 'Recovering the Calvin of "two kingdoms": A historical-theological inquiry in the light of church-state discourse in South Africa', PhD thesis, Deptartment of Systematic Theology and Ecclesiology, Stellenbosch University, Stellenbosch.
Jooste, S.N., 2019, 'Is it ethical for a Christian to treat depression with antidepressants?', Stellenbosch Theological Journal 4(1), 179-198. https://doi.org/ 10.17570/stj.2018.v4n1.a09

Jordaan, G.J.C., 2008, 'Manlik en vroulik in die kerk - nabetragting oor ' $n$ boek en konferensie', paper presented at the 2008 Reformed Theological Symposium of the RCSA, Potchefstroom, 22-23 April.

Manetsch, S.M., 2015, Calvin's company of pastors: Pastoral care and the emerging reformed church, 1536-1609, Oxford Studies in Historical Theology, Oxford University Press, New York, NY.

Maxwell, W.D., 1936, An outline of Christian worship: Its development and forms, Oxford, London.

McNeill, J.T. (ed.), 1954, Calvin: Theological treatises, SCM Press LTD, London.

Muller, R., 2000, The unaccommodated Calvin: Studies in the foundation of a theological tradition, Oxford Studies in Historical Theology, Oxford University Press, New York, NY.

Oliphant Old, H., 1975, Patristic roots of reformed worship, Theologischer Verslag, Zürich.

Oliphant Old, H., 2002, Worship: Reformed according to Scripture, WJKP, Louisville, KY. Reformed Churches in South Africa (RCSA), 2012, Acts of the second general synod at Potchefstroom on 4 January 2012 and following days, V\&R, Pretoria.

Robertson, O.P., 1987, Christ of the covenants, P\&R Publishing, Grand Rapids, MI.

Schaff, P., 1983, The creeds of Christendom, 3 vols., Baker, Grand Rapids, MI.

Ursinus, Z. \& Olevianus, C., [1563] 1983, 'The Heidelberg Catechism', in P. Schaff (ed.), The creeds of Christendom, 3 vols., pp. 307-355, Baker, Grand Rapids, MI.

Ursinus, Z., 1992, The commentary of Dr. Zacharias Ursinus on the Heidelberg catechism, transl. G.W. Willard, P\&R Publishing, Phillipsburg, NJ.

VanDrunen, D., 2010a, Living in God's two kingdoms: A biblical vision for Christ and culture, Crossway, Wheaton, IL.

VanDrunen, D., 2010b, Natural law and the two kingdoms: A study in the development of reformed social thought, Emory Studies in Law and Religion, Eerdmans, Grand Rapids, MI.

VanDrunen, D., 2014, Divine covenants and moral order: A biblical theology of natural law, Eerdmans, Grand Rapids, MI.

Vorster, J.M., 2010, 'Calvin and human dignity', In die Skriflig/In Luce Verbe 44(3), 197-214. https://doi.org/10.4102/ids.v44i0.189

Vorster, J.M., 2016, 'The general revelation of God and creational gifts as a source for bioethics', In die Skriflig/In Luce Verbe 50(1), 1-7. https://doi.org/10.4102/ids. v50i1.2083

Wagner, P., 1901, Gregorian melodies: A handbook of Plainsong, 2nd edn., transl. A. Orme \& E.G.P. Wyatt, Plainsong and Medieval Music Society, London.

Westminster Confession of Faith, 1983, 'The Westminster confession of faith', in P. Schaff (ed.), The creeds of Christendom, 3 vols., Baker, Grand Rapids, MI.

Woolsey, A.A., 2012, Unity and continuity in covenantal thought: A study in the reformed tradition to the Westminster assembly, Reformation Heritage Books, Grand Rapids, MI.

Williamson, G.I., 2001, 'The regulative principle of worship', paper presented at the 2001 International Conference of Reformed Churches, Philadelphia, 20-27th June. 